\title{
Effectiveness of Nasopalatine Nerve Block for Anesthesia of Maxillary Central Incisors after Failure of the Anterior Superior Alveolar Nerve Block Technique
}

\author{
Tufi Neder MEYER \\ Leonardo Lima LEMOS \\ Carolina Neder Matuck do NASCIMENTO \\ William Ricardo Ribeiro de LELLIS (In memoriam) \\ Department of Anatomy and Postgraduate Program, \\ University of Vale do Rio Verde de Três Corações, Três Corações, MG, Brazil
}

\begin{abstract}
The purpose of this study was to assess the effectiveness of nasopalatine nerve block for anesthesia of maxillary central incisors after failure of the anterior superior alveolar nerve (ASAN) block technique. Secondarily, the possible innervation of the maxillary central incisors by the nasopalatine nerve was also investigated. Twenty-seven healthy, young adult volunteers (age: 17-26 years; gender: 9 males and 18 females) were enrolled in this study. All participants were undergraduate dental students of the University of Vale do Rio Verde de Três Corações. The volunteers had the anterior superior alveolar nerves anesthetized and a thermal sensitivity test (cold) was performed on the maxillary central incisors. The volunteers that responded positively to cold stimulus received a nasopalatine nerve block and the thermal sensitivity test was repeated. All participants were anesthetized by a single operator. Three patients presented sensitivity after both types of bilateral blocks and were excluded from the percentage calculations. In the remaining 24 patients, 16 had their maxillary central incisors anesthetized by the anterior superior alveolar block and 8 remained with sensitivity after the ASAN block. All these 8 patients had their maxillary central incisors successfully anesthetized by the nasopalatine block. In this study, 33.3\% of the subjects had the innervation of one or both maxillary central incisors derived from the nasopalatine nerve, whilst most subjects $(66.7 \%)$ had such teeth innervated by the anterior superior alveolar nerve. The nasopalatine nerve block was effective in anesthetizing the maxillary central incisors when the anterior superior alveolar nerve block failed.
\end{abstract}

Key Words: maxillary central incisor, anterior superior alveolar nerve, nasopalatine nerve, local anesthesia failure, tooth innervation.

\section{INTRODUCTION}

When dentists try to anesthetize the maxillary central incisors by anterior superior alveolar nerve (ASAN) block, failures may happen. Apart from technical factors, anatomical issues can also explain such failures. A frequent explanation for this fact is the possibility of innervation of the maxillary central incisor by branches of the nasopalatine nerve (NPN), instead of the usual distribution of dental nerves from the ASAN.

Although this kind of innervation has been mentioned in buccal anatomy and anesthesiology treatises
(1-4), as far as it could be ascertained, there are no published papers referring to this subject on large scientific research databases, such as Medline and LILACS. The German Sicher and Tandler textbook (5), published in 1928, mentions that the NPN can innervate the maxillary central incisor. However, this book has no cited references and the authors do not inform their source to make such a statement. The American Sicher and DuBrul textbook (2) was originated directly from Sicher and Tandler's textbook and the same statement is made, again, without mentioning any references. This fact was repeated in the Brazilian Rizzolo \& Madeira's 
textbook (3). Other textbooks on anatomy used by dentists $(6,7)$ do not mention anything about this question. Another possible anatomic explanation for ASAN block failure is the crossing of ASAN branches from one side to the other of the maxilla, mentioned in two textbooks $(8,9)$, but again, without references to support this statement.

Anyway, it may actually happen that the maxillary central incisor is not adequately anesthetized by ASAN block. How frequently this failure occurs, however, is unknown. The purpose of this study was to assess in human volunteers the effectiveness of nasopalatine nerve block for anesthesia of maxillary central incisors after failure of the anterior superior alveolar nerve block technique. Secondarily, the possible innervation of the maxillary central incisors by the nasopalatine nerve was also investigated.

\section{MATERIAL AND METHODS}

The study methodology was designed in compliance with the guidelines of the Committee on Bioethics of the University Vale do Rio Verde de Três Corações (UNINCOR - Brazil). All subjects were asked to sign an approved informed consent form prior to the anesthetic procedures.

Twenty-seven healthy, young adult volunteers (age: 17-26 years; gender: 9 males and 18 females) were enrolled in this study (Table 1). All participants were undergraduate dental students of the University of Vale do Rio Verde de Três Corações. Other volunteers were excluded from the study. The exclusion criteria were significant anxiety, chronic use of analgesics, major systemic diseases, extensive restorations on the maxillary central incisors, previous endodontic treatment in this tooth and lack of response to the preanesthetic thermal sensitivity test.

Pre and Postanesthetic Sensitivity Testing Protocol. Before anesthesia, all patients were submitted to a thermal sensitivity test (cold stimulus). Empty sterile anesthetic cartridges were filled with water and stored at $4{ }^{\circ} \mathrm{C}$ until ice was formed.The tooth was isolated with gauze and the cartridge was put into contact with the buccal surface of the tooth for up to $20 \mathrm{~s}$, being immediately removed after a painful response. The test was repeated 10 min after the anesthetic procedures.

Anesthetic Protocol. The anesthetic techniques were adapted from Bennett (9). All volunteers were anesthetized using 3\% prilocaine with felipressin $(0.03$ IU/mL; Biopressin; Dentsply Indústria e Comércio Ltda., Petrópolis, RJ, Brazil), in $1.8 \mathrm{~mL}$ cartridges packed in a Carpule syringe (Duflex, S.S.White, Rio de Janeiro, RJ) with a $30 \mathrm{G}$ gingival needle. One cartridge was used for each ASAN block. For the NPN block, $0.6 \mathrm{~mL}$ of the anesthetic solution was used. All patients were anesthetized by a single operator.

\section{RESULTS}

The outcomes of this study are summarized on Table 1 . Three out of 27 subjects presented sensitivity in their maxillary central incisors after both ASAN and NPN blocks and they were excluded from the percentage calculations. Among the remaining 24 patients, 16 (66.7\%) had their maxillary central incisors anesthetized by the anterior superior alveolar block and 8 (33.3\%) remained with sensitivity after the ASAN block. Among these 8 subjects, the ASAN block was effective in anesthetizing the right maxillary central incisor in 5 cases, while the left maxillary central incisor was anesthetized in 1 case. Two other patients had none of their maxillary central incisors anesthetized by the ASAN block. All these 8 patients had their maxillary central incisors successfully anesthetized by the nasopalatine block.

\section{DISCUSSION}

Every type of anesthetic block is subject to failure $(9,10)$ that may have technical, pharmacological or anatomical causes. Failures due to anatomic reasons are usually related to variations in tooth innervation (11). The knowledge of such variations is essential to attaining a high success rate in local anesthetic procedures.

Anesthetic blocks of the maxillary and mandibular central incisors can also fail for such reasons. Mandibular incisors can be innervated by branches of the mylohyoid nerve, a fact that has already been studied in Brazil by cadaver dissections and is well documented (12). Other studies (13-18) have also addressed the supplementary innervation of the mandibular teeth. On the other hand, there is lack of studies referring to the alternative innervation patterns for the maxillary central incisors, although this is mentioned in textbooks of human anatomy. In clinical settings, there is a number of failures when dentists try to block these teeth by 
ASAN block at or inside the infraorbital foramen, which is a technique based on the anatomical information that this nerve is the trunk from which originate the branches that innervate the central incisors. Such failures may be caused by an anatomical variation, that is, the dental nerves originating from the NPN rather from the ASAN.

The present study investigated the failure rate of ASAN block in anesthetizing the maxillary central incisors, as well as the effectiveness of NPN block in anesthetizing these teeth after ASAN block failure. Indirectly, this raises the question on whether the maxillary central incisors can be innervated by the NPN. We have also tried to calculate the rate by which such variation occurs in healthy young adults. The outcomes of this study confirmed that when the ASAN block fails to anesthetize the maxillary central incisor, the NPN block is a viable alternative. In other words, there are clinical findings supporting this alternate innervation pattern. In this study, there was a 2:1 relationship between ASAN and NPN innervation (66.7\% vs. 33.3\%). Furthermore, the results suggest that, when the ASAN does not innervate both maxillary central incisors, the right incisor is preferably supplied with fibers originated from this nerve, while the left maxillary incisor is more frequently innervated by the NPN.

In the present study, there were 3 cases of complete anesthetic failure after both ASAN and NPN blocks. This cannot be explained by anatomical factors.

Table 1. Patient information and results of anesthetic procedures.

\begin{tabular}{|c|c|c|c|c|}
\hline Patient & $\begin{array}{l}\text { Age } \\
\text { (years) }\end{array}$ & Gender & $\begin{array}{l}\text { Teeth anesthetized } \\
\text { by ASANB }\end{array}$ & $\begin{array}{c}\text { Teeth anesthetized } \\
\text { by NPNB }\end{array}$ \\
\hline 1 & 20 & $\mathrm{~F}$ & 11,21 & NPNB not needed \\
\hline 2 & 20 & $\mathrm{~F}$ & 11,21 & NPNB not needed \\
\hline 3 & 19 & $\mathrm{~F}$ & 11,21 & NPNB not needed \\
\hline 4 & 21 & $\mathrm{~F}$ & 11,21 & NPNB not needed \\
\hline 5 & 20 & $\mathrm{~F}$ & 11,21 & NPNB not needed \\
\hline 6 & 21 & $\mathrm{~F}$ & 11,21 & NPNB not needed \\
\hline 7 & 19 & $\mathrm{~F}$ & 11,21 & NPNB not needed \\
\hline 8 & 19 & $\mathrm{~F}$ & 11,21 & NPNB not needed \\
\hline 9 & 19 & $\mathrm{~F}$ & 11,21 & NPNB not needed \\
\hline 10 & 19 & $\mathrm{~F}$ & 11,21 & NPNB not needed \\
\hline 11 & 19 & $\mathrm{~F}$ & 11, 21 & NPNB not needed \\
\hline 12 & 18 & $\mathrm{~F}$ & 11,21 & NPNB not needed \\
\hline 13 & 21 & $\mathrm{~F}$ & 11,21 & NPNB not needed \\
\hline 14 & 26 & M & 11,21 & NPNB not needed \\
\hline 15 & 19 & M & 11,21 & NPNB not needed \\
\hline 16 & 19 & M & 11,21 & NPNB not needed \\
\hline 17 & 17 & M & 21 & 11, 21 \\
\hline 18 & 26 & $\mathrm{~F}$ & 11 & 11, 21 \\
\hline 19 & 18 & M & 11 & 11, 21 \\
\hline 20 & 20 & $\mathrm{~F}$ & 11 & 11,21 \\
\hline 21 & 19 & M & 11 & 11,21 \\
\hline 22 & 19 & M & 11 & 11, 21 \\
\hline 23 & 20 & $\mathrm{~F}$ & None & 11,21 \\
\hline 24 & 19 & M & None & 11, 21 \\
\hline 25 (excluded) & 18 & $\mathrm{~F}$ & None & None \\
\hline 26 (excluded) & 18 & $\mathrm{~F}$ & None & None \\
\hline 27(excluded) & 19 & M & None & None \\
\hline
\end{tabular}

ASANB = anterior superior alveolar nerve block; NPNB = nasopalatine nerve block; 11 = maxillary right central incisor; 21 = maxillary left central incisor. 
The same technique and the same materials were used in all patients and a single operator did all anesthetic blocks. These failures may be attributed to technical factors or defect of the anesthetic agent. These 3 cases were excluded from percentage calculations. However, these reasons cannot be invoked to explain ASAN block failure in 8 patients because all of them were anesthetized by the NPN block. On the other hand, it would be quite unlikely that the small volume of $0.6 \mathrm{~mL}$ used for NPN block could infiltrate through the thick hard palate and reach the dental nerve at the root apex.

An issue that was not directly addressed in this work is the possibility that sensory nerves may cross the midline, innervating contralateral teeth, as it seems to happen with mandibular incisors (19). This could be investigated by blocking the ASAN first at one side and, in case of failure, at the other side. Although we faced difficulties in enrolling the volunteers, in spite of performing all procedures in a single session, it would be desirable to increase the number of subjects in future works, in order to lessen the chances of failures, evaluate cross-innervation and have better statistical background. It is the authors' opinion that this is still a field open to investigation, no matter how old such discussion may seem to be. In daily practice, failures in local anesthesia go on happening today, as they happened in the past.

The findings of this study may provide some benefits, including helping dentists to understand failures of anesthesia of the maxillary central incisors, providing dentists with data to perform nasopalatine nerve blocks in case of failure o ASAN and quantifying the prevalence of an alternate innervation pattern of the maxillary central incisors.

In conclusion, the NPN block was effective when the ASAN block failed to anesthetize the maxillary central incisor. As much as $33.3 \%$ of the subjects had innervation of one or both maxillary central incisors derived from the nasopalatine nerve, while most subjects $(66.7 \%)$ had such teeth innervated by the anterior superior alveolar.

\section{RESUMO}

O objetivo deste estudo foi avaliar a eficácia do bloqueio do nervo nasopalatino após falha na anestesia dos incisivos centrais superiores pelo bloqueio no nervo alveolar superior anterior (NASA). Secundariamente, investigou-se a possível inervação do incisivo central superior por ramos do nervo nasopalatino
(NNP). Foram avaliados 27 voluntários saudáveis, adultos jovens (idade: 17-26 anos; sexo: 9 homens e 18 mulheres). Todos eram estudantes de Odontologia da Faculdade do Vale do Rio Verde de Três Corações. Os voluntários tiveram os nervos alveolares anteriores superiores anestesiados e em seguida foram submetidos a um teste de sensibilidade térmica nos incisivos centrais superiores. Aqueles pacientes que ainda apresentavam sensibilidade após o bloqueio do NASA receberam bloqueio do NNP e então o teste térmico foi repetido. Todos os pacientes foram anestesiados por um único operador. Três pacientes ainda apresentaram sensibilidade após ambos os bloqueios bilaterais (NASA e NNP) e foram excluídos das análises de percentagem. Dos 24 pacientes restantes, 16 tiveram seus incisivos centrais superiores anestesiados pelo bloqueio do NASA e 8 permaneceram com sensibilidade após este procedimento. Estes 8 pacientes submeteram-se ao bloqueio do NNP, o que resultou em sucesso na anestesia dos incisivos centrais superiores. Neste estudo, 33,3\% dos pacientes tinham a inervação de um ou de ambos os incisivos centrais superiores derivada do nervo nasopalatino, enquanto a maioria dos pacientes $(66,7 \%)$ tinha tais dentes inervados pelo nervo alveolar superior anterior. $\mathrm{O}$ bloqueio do NNP foi eficaz para anestesiar os incisivos centrais superiores, nos casos em que falhou o bloqueio do NASA.

\section{REFERENCES}

1. Jastak JT, Yagiela JA. Regional anesthesia of oral cavity. St. Louis: Mosby; 1981.

2. DuBrul EL. Sicher \& DuBrul's oral anatomy. 8th ed. St. Louis: Ishiyaku EuroAmerica; 1988.

3. Rizzolo RJC, Madeira MC. Facial anatomy with fundaments of general systemic anatomy. São Paulo: Sarvier; 2004.

4. Malamed SF. Handbook of local anesthesia. 4th ed. St. Louis: Mosby; 1997.

5. Sicher H, Tandler J. Anatomie für Zahnärzte. Berlin: SpringerVerlag; 1928.

6. Fehrenbach MJ, Herring SW. Illustrated anatomy of the head and neck. 3rd ed. Philadelphia: Elsevier; 2007.

7. Scott JH, Dixon AD. Anatomy for students of dentistry. 4th ed. Edinburgh: Churchill Livingstone; 1978.

8. Nevin M, Nevin HR. Problems in dental local anesthesia. 2nd ed. New York: Dental Items of Interest Publishing Company; 1954.

9. Bennett CR. Monheim's local anesthesia and pain control in dental practice. 7th ed. St. Louis: CV Mosby; 1978.

10. Blanton PL, Jeske AH. The key to profound local anesthesia: neuroanatomy. J Am Dent Assoc 2003;134:753-760.

11. Heasman PA. Clinical anatomy of the superior alveolar nerves. Br J Oral Maxillofac Surg 1984;22:439-447.

12. Madeira MC, Percinoto C, Silva MGM. Clinical significance of supplementary innervation of the lower incisor teeth: a dissection study of the mylohyoid nerve. Oral Surg Oral Med Oral Pathol 1978;46:608-601.

13. Adatia AK. Innervation of mandibular central incisors. Brit Dent J 1978;145:43-46.

14. Masuko TS, Rosenberg B, Francisco M, Picosse LR. Contribution to the study of supplementary innervation of mandibular teeth - A review of literature. Rev Fac Odont FZL 1989;1:5562 .

15. Reynes P, Duran D, Guiraud P, Guichard M. Les échecs de l'anesthésie des incisives centrales et des molaires 
mandibulaires: le problème des suppléances nerveuses. Rev Odontostomatol (Paris) 1983;12:55-61.

16. Rizzolo RJC, Madeira MC, Bernaba JM, Freitas V. Clinical significance of the supplementary innervation of the mandibular teeth: a dissection study of the transverse cervical (cutaneous colli) nerve. Quintessence Int 1988;19:167-169.

17. Rood JP. The analgesia and innervation of mandibular teeth. Br Dent J 1976;140:237-239.
18. Roda RS, Blanton PL. The anatomy of local anesthesia. Quintessence Int 1994;25:27-38.

19. Yonchak T, Reader A, Beck M, Myers WJ. Anesthetic efficacy of unilateral and bilateral nerve blocks to determine cross innervation in anterior teeth. Oral Surg Oral Med Oral Pathol Oral Radiol Endod 2001;92:132-134.

Accepted February 19, 2005 